\title{
The politics of neoliberalisation and resistance in post-crash Northern Ireland: A reply to Byers
}

\author{
Dr Matthew Johnson \\ m.johnson@lancaster.ac.uk
}

This is an Author's Original Manuscript (AOM) of an article published by Bristol University Press in Global Discourse on 22 September 2019, available online: http://dx.doi.org/ $10.1332 / 204378919 X 15646708719788$

\section{Biography}

Matthew Johnson is Lecturer in Politics in the Department of Politics, Philosophy and Religion at Lancaster University, Bailrigg, Lancaster, LA1 4YL, United Kingdom; email: m.johnson@lancs.ac.uk. His research focuses on the relationship between culture, public policy and wellbeing, examining such topics as informal welfare systems, indigenous politics and genital cutting. He is founding editor of Global Discourse (tandfonline.com/loi/rgld20) and author of Evaluating Culture (London: Palgrave MacMillan, 2013).

\begin{abstract}
Seán Byers (2019) presents a comprehensive overview of the post-crash political landscape in Northern Ireland. His most significant contribution is, perhaps, the most understated: that the Blairite settlement is incapable of resolving the social cleavages that threaten any possibility of harmony. He highlights, again and again, the ways in which apparently divergent actors, such as Sinn Fein and the DUP are brought together through the demands of neoliberal governance and, in so doing, deprive their working class electorates of real change. In this reply, I argue that the current situation highlights the need for genuine transformative politics and that this is most likely to come from Britain, not the Republic.
\end{abstract}

Keywords: Northern Ireland; New Labour; Sinn Fein; DUP; Socialism

In his article, Seán Byers (2019) presents a comprehensive overview of the post-crash political landscape in Northern Ireland. His most significant contribution is, perhaps, the most understated: that the Blairite settlement is incapable of resolving the social cleavages that threaten any possibility of harmony. He highlights, again and again, the ways in which apparently divergent actors, such as Sinn Fein and the DUP are brought together through the demands of neoliberal governance and, in so doing, deprive their working class electorates of real change.

As Hindmoor (2018) and others have demonstrated, New Labour's nonconfrontational, non-conflictual politics defined a 'centrist' mentality that regarded old class antagonisms as not just irrelevant, but unhelpful. By shifting dialogue away from dogmatism to pragmatism, ideology to evidence, conflict to consensus, class to identity, social justice to social mobility, the key proponents of neoliberalism sought to ensure transcendence of the politics of old in achieving the evidence-based, technocratic politics of the future. Given that so many of the architects of New Labour began life as Marxists, it should be no surprise that they adopted teleological visions of the reconciliation of the subjective with the objective and in shifting from the administration of people to the administration of things.

Byers brilliantly highlights the ways in which parties and actors undertook a course of adoption of this disposition as a precondition of electoral success and of government. He shows that, just as New Labour dispensed with opposition to capitalism and compartmentalised it as an inevitable feature of modern society, while promoting concern for 'progressive' identity 
politics as the basis for social justice through social mobility, Sinn Fein came to accommodate swingeing neoliberal approaches to austerity. While we might take the DUP's position on the economy for granted, the fact that they were willing to recognise Sinn Fein as a legitimate political actor and representation of 'a' community suggests that they, too, bought into modern identity politics, even if they notionally disagreed with Sinn Fein, as with same sex marriage, about which identities might be recognised.

The consequence, of course, was that the basis of the conflict - radical inequalities of wealth, often attached to ethno-cultural identities - has not been addressed and that New Labour's ability to massage that conflict through subsidies and EU investment was concealed by their public rejection of state intervention.

The big problem, then, is that, having adopted New Labour mentalities, the political actors in Northern Ireland now look, bizarrely, out of touch with events on the ground. While the DUP are clearly at odds with the mainland British mainstream with which they claim to identify, by attempting to enter Government in the South, Sinn Fein look increasingly out of touch with the needs and interests of communities in the North. While British politics is looking increasingly radical and, through Labour and the SNP, increasingly left-wing in economic affairs, Irish politics remains fervently neoliberal, with little appetite on the part of the state to intervene in the economy or health or any number of other areas in which the state, and only the state, can make a transformative difference. The Republic, with its New Labour politics of neoliberalism and identity politics, is both far less radical and far less capable of making any serious inroads to the problems faced, not just in its own society, but especially in the North.

As a consequence, not only do the DUP run the risk of making clear the apparent cultural differences between their cohort and the British mainstream, Sinn Fein run the risk of making the limitations of unification with the South all too apparent to Northern republicans.

This is apparent in Byers' (2019) article. Again and again he talks of the value of existing health, social and economic protections that stem from Britain's post-1945 settlement and the impact and transformative potential of 'British' institutions, such as Unite. Where there is reference to the impact of 'Irish' influence on Sinn Fein, it is with regard, for example, to the need to demonstrate commitment to neoliberalism to appeal to Irish American financiers.

This all turns a number of narratives on their head: it is British, not Irish, politics that has introduced or has the potential to introduce the kind of substantive changes to Northern Ireland that might actually deal with the underlying causes of conflict. The neoliberal consensus demonstrates, simply, that no amount of identity politics, no amount of road signs in different languages, no amount of inter-community recognition of difference will lead us to the kind of settlement that might stop general social decay, chronic health inequalities and kids shooting journalists.

The fact that Britain is the 'oppressor' in this instance, and that Britain appears headed toward an unpredictable departure from the EU that so many regard as regressive, makes that conclusion counter-intuitive. However, the Republic's total failure to challenge neoliberalism and the failure of the main Republican parties in Northern Ireland to uphold radical, progressive socio-economic commitments demonstrates the need for party politics capable of capturing the class interests of those across the 'two' communities.

Given the transformative politics of Corbyn's Labour (see, for example, Standing 2019), and given the absolute dissolution of any notion of the SDLP's being a left-wing party (Hanna 2019), one first step toward dealing with the present situation should be to stand candidates in each constituency in the North. Whether electorally successful or not, having a party committed to socio-economic transformation pushing other parties has the capacity to shift discourse leftward, as the Tories' concessions on neoliberalism have illustrated.

\section{References}


Byers, S. (2019) 'The politics of neoliberalisation and resistance in post-crash Northern Ireland', Global Discourse, 9:3.

Hanna, C. (2019) 'SDLP will be the loser in merger with Fianna Fáil', The Irish Times, 8 February, <https://www.irishtimes.com/opinion/sdlp-will-be-the-loser-in-mergerwith-fianna-f\%C3\%A1il-1.3785852> [Accessed 11 June 2019].

Hindmoor, A. (2018) 'Why the left's hellish vision is so ruinous', The Guardian, 11 March, <https://www.theguardian.com/commentisfree/2018/mar/11/why-the-lefts-hellishvision-is-so-ruinous> [Accessed 11 June 2019].

Standing, G. (2019) Basic Income as Common Dividends: Piloting a Transformative Policy: A Report for the Shadow Chancellor of the Exchequer, Progressive Economic Forum: London, <https://www.progressiveeconomyforum.com/wpcontent/uploads/2019/05/PEF_Piloting_Basic_Income_Guy_Standing.pdf $>$ [Accessed 08 May 2019]. 